\title{
Comparison of Clinical Scoring Systems in the Management of Patients with Microangiopathic Hemolytic Anemia and Thrombocytopenia
}

\author{
Mikroanjiyopatik Hemolitik Anemi ve Trombositopenili Hastaların Yönetiminde Klinik \\ Skorlama Sistemlerinin Karşılaştırılması
}

\author{
(D) Mehmet Baysal, (D) Elif Ümit, (D) Hakkı Onur Kırkızlar, (D) Ahmet Muzaffer Demir \\ Trakya University Faculty of Medicine, Department of Hematology, Edirne, Turkey
}

\section{Abstract}

Objective: Several clinical scoring systems have been developed for the differential diagnosis of thrombotic microangiopathies (TMAs), all to predict and identify patients with ADAMTS13 deficiency and to start treatment as soon as possible. The first scoring system in this regard was the Bentley score, and the French score and PLASMIC score were developed afterwards.

Materials and Methods: We aimed to evaluate the laboratory parameters and clinical features of patients who underwent plasma exchange with a prediagnosis of TTP at our clinic between 2007 and 2019 and whose ADAMTS13 enzyme levels were measured and to compare the findings with the scoring systems.

Results: Data of 35 patients were evaluated. Twelve patients were evaluated as high risk according to all three scoring systems. A statistically significant relation was observed between all three scoring systems and ADAMTS13 levels.

Conclusion: A moderate correlation was found between all three scoring systems and ADAMTS13 levels. We observed similar potential strength of all three scoring systems to predict TP among other TMAs and we conclude that they are applicable in daily practice.

Keywords: Thrombotic thrombocytopenic purpura, PLASMIC score, Thrombotic microangiopathy, French score, Bentley score

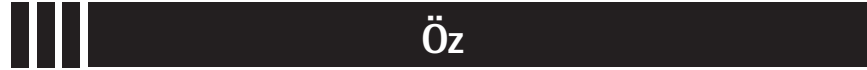

Amaç: Trombotik mikroanjiyopatilerin (TMA) ayırıcı tanısı yapabilmek ve ADAMTS13 eksikliği olan hastaları ayırt edebilmek için çeşitli klinik skorlama sistemleri geliştirilmiştir. Bu konuda ilk geliştirilen skorlama sistemi Bentley skoru olup; French ve PLASMIC skorları daha sonra geliştirimiştir.

Gereç ve Yöntemler: 2007-2019 yılları arasında kliniğimizde trombotik trombositopenik purpura (TTP) ön tanısıyla plazma değişimi yapılan ve ADAMTS13 enzim düzeyi ölçülen hastaların klinik özellikleri ve laboratuvar verilerini her üç skorlama sistemine göre karşılaştırılmayı amaçladık.

Bulgular: Otuz beş hastanın verileri geriye dönük olarak değerlendirildi. Her üç skorlama sistemine göre 12 hasta yüksek riskli olarak değerlendirildi. Skorlama sistemleri ve ADAMTS13 seviyeleri arasında istatistiksel olarak anlamlı bir ilişki gözlendi. Ayrıca, skorlama sistemleri ile ADAMTS13 seviyeleri arasında orta düzeyde bir korelasyon bulundu.

Sonuç: Her üç skorlama sisteminin günlük pratikte kolayca uygulanabilir olması ile birlikte; TP ön tanısı olan hastaları ayırt etmede benzer bir potansiyel güçte olduğunu gözlemledik.

Anahtar Sözcükler: Trombotik trombositopenik purpura, PLASMIC skor, Trombotik mikroanjiyopati, Klinik skorlama sistemleri, Bentley skoru

\section{Introduction}

Thrombotic thrombocytopenic purpura (TP) is a thrombotic microangiopathy (TMA) characterized by microangiopathic hemolytic anemia and thrombocytopenia developed due to deficiency of ADAMTS13 (a disintegrin and metalloprotease with thrombospondin type 1 repeats, member 13) [1]. The ADAMTS13 enzyme is responsible for controlling the length of the von Willebrand factor (vWF) multimers and the absence of ADAMTS13 activity causes the formation of very large (ultralarge) vWF multimers, which have an increased tendency to attach to the endothelium [2]. The difference between TP and other TMAs including hemolytic uremic syndrome (HUS), atypical HUS, complement-mediated TMA, and drug-induced TMA is basically the deficiency of ADAMTS13 enzyme activity

- Copyright 2021 by Turkish Society of Hematology

Turkish Journal of Hematology, Published by Galenos Publishing House

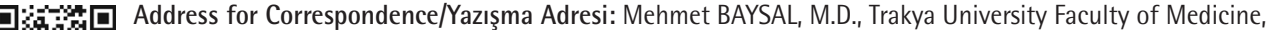
Department of Hematology, Edirne, Turkey

Phone : +90535966 4188

E-mail : drmehmetbaysal@gmail.com ORCID: orcid.org/0000-0001-7681-4623 
$[2,3]$. Accepted as a rare disease, the estimated and reported incidence of TTP is 2-3 persons per 1 million with a female predominance [4]. The treatment of TTP entails emergency plasma exchange and, to overcome that challenging emergency situation, several clinical scoring systems of probability have been developed and proposed [5]. With the use of these clinical scoring systems it is aimed to identify patients with ADAMTS13 deficiency and to start plasma replacement treatment as soon as possible.

The first scoring system in this regard was the Bentley score, which was followed by the French score and PLASMIC score. The Bentley score was developed with a retrospective analysis of 110 patients and 5 laboratory parameters were suggested to be significantly correlated with ADAMTS13 levels [6]. Validation of the Bentley score was performed afterwards with a cohort with 84 patients [7]. The second score was called the French score, based on the analysis of 214 patients and including platelet count, creatinine level, and antinuclear antibody (ANA) [8]. Although these scoring systems were based on studies with significant numbers of patients, they were never popular in daily practice. The last one was called the PLASMIC score, developed based on the data of the Harvard TMA registry and validated with several studies $[5,9,10,11]$.

Determination of the ADAMTS13 level is essential for the definitive diagnosis of TTP as well as for monitoring the course of the disease. Since the determination of ADAMTS13 enzyme activity is performed in specialized centers and laboratories, requiring a significant amount of time, it has become a goal for clinicians to predict possible TP patients in order to start the lifesaving treatment.
In our study, we aimed to evaluate the laboratory parameters and clinical features of patients who underwent plasma exchange with a prediagnosis of TP at our clinic between 2007 and 2019 and whose ADAMTS13 enzyme levels were measured and to compare those findings with the scoring systems.

\section{Materials and Methods}

Our study was designed as a retrospective study. Data of patients who underwent plasma exchange with a prediagnosis of TTP between 2007 and 2019 were evaluated. The Bentley score, French score, and PLASMIC score were calculated based on the data of patient files. Calculations and interpretations of the clinical scoring systems are summarized in Table 1.

Samples for ADAMTS13 activity level determination were collected before plasma exchange initiation from a citrated plasma sample. The samples were centrifuged and stored at $-80^{\circ} \mathrm{C}$ before assessment. The enzyme-linked immunosorbent assay (ELISA) method was used to measure ADAMTS13 activity. Severe ADAMTS13 deficiency was defined as an ADAMTS activity level lower than $10 \%[1,12,13,14]$. In statistical analysis, continuous variables were represented as mean \pm standard derivation. For categorical variables, the chi-square test was used. Correlation analysis was performed using Spearman tests.

\section{Statistical Analysis}

SPSS 22.0 (IBM Corp., Armonk, NY, USA) was used for statistical analysis and a two-sided $p$-value less than or equal to 0.05 was considered as statistically significant.

\begin{tabular}{|c|c|c|c|}
\hline & PLASMIC score & French score & Bentley score \\
\hline Platelet count & $<30 \times 10^{9} / \mathrm{L}: 1$ point & $\leq 30 \times 10^{9} / \mathrm{L}: 1$ point & $>35 \times 10^{9} / \mathrm{L}:-30$ points \\
\hline Parameters of hemolysis & $\begin{array}{l}\text { Reticulocyte count >2.5\%: } 1 \text { point } \\
\text { Haptoglobin undetectable: } 1 \text { point } \\
\text { Indirect bilirubin }>2 \mathrm{mg} / \mathrm{dL}: 1 \text { point }\end{array}$ & & $\begin{array}{l}\text { Reticulocyte count }>3 \%:+21 \text { points } \\
\text { Indirect bilirubin }>1.5 \mathrm{mg} / \mathrm{dL}:+20.5 \\
\text { points }\end{array}$ \\
\hline MCV & $<90 \mathrm{fL}: 1$ point & & \\
\hline INR & $<1.5: 1$ point & & \\
\hline Low & $0-4$ & 0 & $<20$ \\
\hline Intermediate & 5 & 1 & $20-30$ \\
\hline High & $6-7$ & $2-3$ & $>30$ \\
\hline
\end{tabular}


Our study was carried out in accordance with the 1964 Declaration of Helsinki and its later amendments. Ethics committee approval was obtained from the local ethics board (TUTF-BAEK 2020-214).

\section{Results}

A total of 35 patients were evaluated; 25 patients were female and 10 patients were male. The ages of the patients ranged from 20 to 84 years with an average age of 45.91. Demographic and laboratory features of the patients are given in Table 2. According to the PLASMIC scores, 13 patients were evaluated as high risk, 10 patients as moderate risk, and 12 as low risk. When the Bentley and French scoring systems were evaluated, by both scoring systems 19 patients were evaluated as high risk, 11 patients as moderate risk, and 5 patients as low risk (Table 3). A total of 12 patients were evaluated as high risk according to all 3 scoring systems. In addition, patients were divided into 2 groups according to ADAMTS13 activity levels of $<10 \%$ and $>10 \%$, and clinical scoring systems were compared for these groups. In statistical analysis using the chi-square method, a significant relationship was found between all 3 scoring systems and ADAMTS13 levels $(p<0.05)$ (Table 4). In addition, the relationship between scoring systems and ADAMTS13 levels was evaluated by Spearman correlation analysis and a strong positive correlation was found between all 3 scoring systems and ADAMTS13 levels (Table 5). In the final evaluation of the patients, 23 were diagnosed with TTP (for ADAMTS activity levels of $<10 \%$ ), 4 were diagnosed with HUS, 3 were diagnosed with primary autoimmune/rheumatologic disease, 2 were diagnosed with sepsis/infection, 2 were diagnosed with atypical HUS, and 1 was diagnosed with drug-induced thrombotic microangiopathy.

\section{Discussion}

TTP was first described by Moschcowitz in 1925. He reported a 16-year-old girl presenting with bleeding, hematuria, and neurologic symptoms [15]. Later, in a landmark paper in 1966, it was defined as a constellation of symptoms including microangiopathic anemia, thrombocytopenia, fever, neurologic signs, and renal failure. Fragmented erythrocytes also called schistocytes were observed on peripheral blood smears as an indicator of microangiopathic hemolytic anemia [16]. The pathophysiology was unclear until the 1990s, when the contribution of vWF due to deficiency of ADAMTS13 enzyme, which cleaves the ultra-large multimers, was discovered to be the missing piece [16].

In spite of these developments in the pathophysiology and pathobiology of TMAs, the clinical picture of TTP remains challenging for physicians. Few of the five symptoms of the classical pentad were clinically demonstrated in patients $[3,12,17]$. Although ADAMTS13 enzyme level measurement remains the most essential parameter, assessment of ADAMTS13 level is only possible in specialized laboratories, requiring time to obtain the sample and perform the analysis itself. This remains the most challenging issue around the world. For this reason, various clinical predictive scoring systems have been developed to diagnose ТР. The main aim here is to distinguish patients who will benefit from emergency plasma exchange treatment until the laboratory assessment of ADAMTS13. Despite the fact that plasma exchange is the most successful treatment for TP to date, central catheter insertion is required and plasma exchange therapy itself may have serious side effects. Therefore, evaluation of clinical scoring systems in TP-suspected patients remains critically important.

\begin{tabular}{|l|l|}
\hline Table 2. Demographic and laboratory features of the study population. \\
\hline Characteristics and laboratory features & Mean (minimum-maximum) \\
\hline Age & $45.91(20-84)$ \\
\hline Gender & 25 female/10 male \\
\hline Hemoglobin, g/dL & $7.7(4.8-10.5)$ \\
\hline LDH level, U/L & $887(366-2086) ;$ reference range: <246 U/L \\
\hline ADAMTS13 activity, \% & $32.2(0.2-98.4)$ \\
\hline Platelet count, x109/L & $36.7(8-106)$ \\
\hline Creatinine level, $\mathrm{mg} / \mathrm{dL}$ & $1.76(0.7-4.4)$ \\
\hline Reticulocyte count, \% & $4.8(1.2-12.6)$ \\
\hline INR & $1.2(0.9-18) ;$ reference range: $1-1.5$ \\
\hline LDH: Lactate dehydrogenase, INR: international normalized ratio. & \\
\hline
\end{tabular}

Table 3. Distribution of patients by clinical scoring systems.

\begin{tabular}{|l|l|l|l|}
\hline & PLASMIC score & French score & Bentley score \\
\hline Low & $10(28.6 \%)$ & $5(14.3 \%)$ & $5(14.3 \%)$ \\
\hline Intermediate & $12(34.3 \%)$ & $11(31.4 \%)$ & $11(31.4 \%)$ \\
\hline
\end{tabular}




\begin{tabular}{|c|c|c|c|}
\hline & \multicolumn{2}{|c|}{ ADAMTS13 activity level } & p-value \\
\hline PLASMIC score evaluation & $>10 \%$ & $<10 \%$ & \multirow{4}{*}{0.001} \\
\hline Low risk & 10 & 0 & \\
\hline Intermediate risk & 0 & 12 & \\
\hline \multirow[t]{2}{*}{ High risk } & 1 & 12 & \\
\hline & \multicolumn{2}{|c|}{ ADAMTS13 activity level } & $p$-value \\
\hline French score evaluation & $>10 \%$ & $<10 \%$ & \multirow{4}{*}{0.001} \\
\hline Low risk & 5 & 0 & \\
\hline Intermediate risk & 4 & 7 & \\
\hline \multirow[t]{2}{*}{ High risk } & 2 & 17 & \\
\hline & \multicolumn{2}{|c|}{ ADAMTS13 activity levels } & p-value \\
\hline Bentley score evaluation & $>10 \%$ & $<10 \%$ & \multirow{4}{*}{0.001} \\
\hline Low risk & 5 & 0 & \\
\hline Intermediate risk & 4 & 7 & \\
\hline High risk & 2 & 17 & \\
\hline
\end{tabular}

\begin{tabular}{|l|l|l|}
\hline \multicolumn{3}{|l|}{ Table 5. Spearman correlation analysis results between scoring systems and ADAMTS13 levels. } \\
\hline Clinical scoring systems & Spearman correlation coefficient & p-value \\
\hline PLASMIC score & 0.738 & 0.001 \\
\hline French score & 0.590 & 0.001 \\
\hline Bentley score & 0.590 & 0.001 \\
\hline
\end{tabular}

The PLASMIC score was designed and externally validated in a cohort of 214 patients. In that analysis, the authors stated that both the Bentley score and French score, though much easier to calculate, have weaknesses in detecting TP, including their lack of external validation [5]. The autoimmune nature of the disease and the promising results obtained by adding rituximab shows us that ANA positivity, which was included in the French score, could be a reasonable marker $[18,19,20]$. In a recent analysis with limited patients, it was also suggested that adding the ratio of lactate dehydrogenase level/upper normal limit could strengthen the value of the PLASMIC score [21]. Considering all this together, while no scoring system is definitive, each has its own strengths and weaknesses. Therefore, physicians and clinicians should determine how to interpret them and use them in certain situations.

The small sample size is a weakness of our study. However, for rare diseases such as TTP, it is hard to perform studies with larger sample sizes. TP diagnosis and treatment are urgent emergencies and action must be taken immediately. With these scoring systems, rapid plasmapheresis treatment is recommended for high-risk patients. In our study with a limited number of patients, we found that there was no difference between the scoring systems. Our findings need to be evaluated with studies involving more patients.

Informed Consent: Written informed consent was obtained from all patients.

\section{Authorship Contributions}

Concept: M.B.; Design: M.B., E.Ü.; Data Collection or Processing: M.B.; Analysis or Interpretation: H.O.K., A.M.D.; Literature Search: M.B.; Writing: M.B., E.Ü.

Conflict of Interest: No conflict of interest was declared by the authors.

Financial Disclosure: The authors declared that this study received no financial support.

\section{References}

1. Joly BS, Coppo P, Veyradier A. Thrombotic thrombocytopenic purpura. Blood 2017;129:2836-2846.

2. Mörtzell $M$, Berlin $G$, Nilsson $T$, Axelsson CG, Efvergren $M$, Audzijoni J, Griskevicius A, Ptak J, Blaha M, Tomsova H, Liumbruno GM, Centoni P, Newman E, Eloot S, Dhondt A, Tomaz J, Witt V, Rock G, Stegmayr B. Thrombotic microangiopathy. Transfus Apher Sci 2011;45:119-123.

3. Tekgündüz E, Yılmaz M, Erkurt MA, Kiki I, Kaya AH, Kaynar L, Alacacioglu I, Cetin G, Ozarslan I, Kuku I, Sincan G, Salim O, Namdaroglu S, Karakus A, Karakus V, Altuntas F, Sari I, Ozet G, Aydogdu I, Okan V, Kaya E, Yildirim R, Yildizhan E, Ozgur G, Ozcebe OI, Payzin B, Akpinar S, Demirkan F. A multicenter experience of thrombotic microangiopathies in Turkey: the Turkish Hematology Research and Education Group (ThREG)-TMA01 study. Transfus Apher Sci 2018;57:27-30.

4. Mariotte E, Azoulay E, Galicier L, Rondeau E, Zouiti F, Boisseau P, Poullin $P$, de Maistre $E$, Provôt $F$, Delmas $Y$, Perez $P$, Benhamou $Y$, Stepanian A, Coppo P, Veyradier A; French Reference Center for Thrombotic Microangiopathies. Epidemiology and pathophysiology of adulthoodonset thrombotic microangiopathy with severe ADAMTS13 deficiency 
(thrombotic thrombocytopenic purpura): a cross-sectional analysis of the French national registry for thrombotic microangiopathy. Lancet Haematol 2016;3:e237-e245.

5. Bendapudi PK, Hurwitz S, Fry A, Marques MB, Waldo SW, Li A, Sun L, Upadhyay V, Hamdan A, Brunner AM, Gansner JM, Viswanathan S, Kaufman RM, Uhl L, Stowell CP, Dzik WH, Makar RS. Derivation and external validation of the PLASMIC score for rapid assessment of adults with thrombotic microangiopathies: a cohort study. Lancet Haematol 2017;4:e157-e164.

6. Bentley MJ, Lehman CM, Blaylock RC, Wilson AR, Rodgers GM. The utility of patient characteristics in predicting severe ADAMTS13 deficiency and response to plasma exchange. Transfusion 2010;50:1654-1664.

7. Bentley MJ, Wilson AR, Rodgers GM. Performance of a clinical prediction score for thrombotic thrombocytopenic purpura in an independent cohort. Vox Sang 2013;105:313-318.

8. Coppo $P$, Schwarzinger $M$, Buffet $M$, Wynckel $A$, Clabault $K$, Presne $C$, Poullin P, Malot S, Vanhille P, Azoulay E, Galicier L, Lemiale V, Mira JP, Ridel C, Rondeau E, Pourrat J, Girault S, Bordessoule D, Saheb S, Ramakers M, Hamidou M, Vernant JP, Guidet B, Wolf M, Veyradier A; French Reference Center for Thrombotic Microangiopathies. Predictive features of severe acquired ADAMTS13 deficiency in idiopathic thrombotic microangiopathies: the French TMA reference center experience. PLoS One 2010;5:e10208.

9. Li A, Khalighi PR, Wu Q, Garcia DA. External validation of the PLASMIC score: a clinical prediction tool for thrombotic thrombocytopenic purpura diagnosis and treatment. J Thromb Haemost 2018;16:164-169.

10. Tang N, Wang $X$, Li D, Sun Z. Validation of the PLASMIC score, a clinical prediction tool for thrombotic thrombocytopenic purpura diagnosis, in Chinese patients. Thromb Res 2018;172:9-13.

11. Tiscia GL, Ostuni A, Cascavilla N, Cappucci F, Scalzulli P, Battista C, Abrescia A, Aucella F, Buquicchio C, Brigante M, D'Andrea G, Di Paolo B, Giordano G, Infante B, Piano S, Ranieri P, Tullo L, Grandone E. Validation of PLASMIC score and follow-up data in a cohort of patients with suspected microangiopathies from Southern Italy. J Thromb Thrombolysis 2018:46:174-179

12. Jang MJ, Chong SY, Kim IH, Kim JH, Jung CW, Kim JY, Park JC, Lee SM, Kim YK, Lee JE, Jang SS, Kim JS, Jo DY, Zang DY, Lee YY, Yhim HY, Oh D.
Clinical features of severe acquired ADAMTS13 deficiency in thrombotic thrombocytopenic purpura: the Korean TP registry experience. Int J Hematol 2011;93:163-169.

13. Shah N, Rutherford C, Matevosyan K, Shen YM, Sarode R. Role of ADAMTS13 in the management of thrombotic microangiopathies including thrombotic thrombocytopenic purpura (TTP). Br J Haematol 2013;163:514-519.

14. Kim $\mathrm{CH}$, Simmons SC, Williams LA 3rd, Staley EM, Zheng $\mathrm{XL}$, Pham HP. ADAMTS13 test and/or PLASMIC clinical score in management of acquired thrombotic thrombocytopenic purpura: a cost-effective analysis. Transfusion 2017; 57:2609-2618.

15. Moschcowitz E. An acute febrile pleiochromic anemia with hyaline thrombosis of the terminal arterioles and capillaries; an undescribed disease. Am J Med 1952;13:567-569.

16. Lämmle B, Kremer Hovinga JA, Alberio L. Thrombotic thrombocytopenic purpura. J Thromb Haemost 2005;3:1663-1675.

17. Scully M, Yarranton H, Liesner R, Cavenagh J, Hunt B, Benjamin S, Bevan D, Mackie I, Machin S. Regional UK TTP Registry: correlation with laboratory ADAMTS 13 analysis and clinical features. Br J Haematol 2008;142:819-826.

18. Scully M, McDonald V, Cavenagh J, Hunt BJ, Longair I, Cohen H, Machin SJ. A phase 2 study of the safety and efficacy of rituximab with plasma exchange in acute acquired thrombotic thrombocytopenic purpura. Blood 2011;118:1746-1753.

19. Westwood JP, Webster H, McGuckin S, McDonald V, Machin SJ, Scully M. Rituximab for thrombotic thrombocytopenic purpura: benefit of early administration during acute episodes and use of prophylaxis to prevent relapse. J Thromb Haemost 2013;11:481-490.

20. Zwicker JI, Muia J, Dolatshahi L, Westfield LA, Nieters P, Rodrigues A, Hamdan A, Antun AG, Metjian A, Sadler JE; ART Investigators. Adjuvant low-dose rituximab and plasma exchange for acquired TTP. Blood 2019;134:11061109.

21. Zhao N, Zhou L, Hu X, Sun G, Chen C, Fan X, Zhou S, Tao X, Liu H, Zheng C. A modified PLASMIC score including the lactate dehydrogenase/the upper limit of normal ratio more accurately identifies Chinese thrombotic thrombocytopenic purpura patients than the original PLASMIC score. J Clin Apher 2020;35:79-85. 